\title{
PUDARNYA PENGGUNAAN BAHASA INDONESIA DI KALANGAN REMAJA
}

\author{
Asruni Samad $^{1 \text {, }}$, Dirfantara Hairuddin ${ }^{2)}$, Kartika Digna Ratmila ${ }^{3)}$ \\ ${ }^{1,2,3)}$ Fakultas Sastra, Universitas Muslim Indonesia \\ Jalan Urip Sumoharjo KM 5, Makassar \\ Email: asrunysamad1198@gmail.com
}

\begin{abstract}
Abstrak
Secara sederhana, bahasa dapat diartikan sebagai alat untuk menyampaikan sesuatu yang terlintas di dalam hati. Namun, lebih jauh bahasa adalah alat untuk beriteraksi atau alat untuk berkomunikasi, dalam arti alat untuk menyampaikan pikiran, gagasan, konsep atau perasaan. Dalam studi sosiolinguistik, bahasa diartikan sebagai sebuah sistem lambang, berupa bunyi, bersifat arbitrer, produktif, dinamis, beragam dan manusiawi. Pengertian Bahasa dalam kamus besar Bahasa Indonesia, pengertian bahasa secara umum dapat didefenisikan sebagai lambang, serta pengertian bahasa menurut istilah adalah alat komunikasi yang berupa sistem lambang yang dihasilkan oleh alat ucap pada manusia. Bahasa juga merupakan bagian dari kebudayaan dan bahasalah yang mengembangkan kebudayaan sebagaimana kita kenal sekarang. Bahasa dapat pula berperan sebagai alat integrasi sosial sekaligus alat adaptasi sosial, hal ini mengingat bahwa Bahasa Indonesia memiliki bahasa yang majemuk. Bahasa gaul adalah bahasa khas remaja (kata-kata yang diubah-ubah sedemikian rupa, sehingga hanya bisa di mengerti di antara mereka) bisa di pahami oleh hamper seluruh remaja di tanah air yang terjangkau oleh media massa. Padahal istilah-istilah itu berkembang, berubah dan bertambah hampir setiap hari. Bahasa gaul adalah bahasa yang mempunyai istilah yang unik, sedangkang defenisi yang kedua di perjelas lagi bahwa yang menggunakan bahasa tersebut adalah para remaja dan bahasa tersebut akan terus berkembang. Adapun ciri-ciri bahasa gaul, faktor-faktor pendukung maraknya bahasa gaul di kaangan remaja, pengaruh bahasa gaul terhadap bahasa Indonesia dan dampak dari penggunaan bahasa gaul.
\end{abstract}

Kata Kunci : Penggunaan, Bahasa Indonesia, Bahasa Gaul

\section{PENDAHULUAN}

Dalam kehidupan sehari-hari manusia tidak terlepas dari pemakaian bahasa. Dengan bahasa seseorang dapat mengungkapkan ide, gagasan, pikiran, dan keinginan dalam menyampaikan pendapat dan informasi. Bahasa sebagai alat untuk interaksi antar manusia dalam masyarakat memiliki sifat sosial yaitu pemakaian bahasa digunakan oleh setiap lapisan masyarakat. Bahasa bukan individual yang hanya dapat dipakai dan dipahami oleh penutur saja akan tetapi, pemakaian bahasa akan lebih tepat bila antara penutur dan mitra tutur saling memahami makna tutur.
Sebagai masyarakat Indonesia tentunya kita menggunakan

Bahasa Indonesia sebagai bahasa nasional, yang berfungsi sebagai alat komunikasi mempunyai peran sebagai penyampai informasi. Namun, pemakaian bahasa Indonesia dalam kehidupan seharihari mulai bergeser digantikan oleh pemakaian bahasa anak remaja yang dikenal dengan bahasa gaul. Interferensi bahasa gaul kadang muncul dalam penggunaan bahasa Indonesia dalam situasi resmi yang mengakibatkan penggunaan bahasa tidak baik dan tidak benar. Sehubungan dengan semakin 
maraknya penggunaan bahasa gaul yang digunakan oleh sebagian masyarakat modern, perlu adanya tindakan dari semua pihak yang peduli terhadap eksistensi bahasa Indonesia yang merupakan bahasa nasional, bahasa persatuan, dan bahasa pengantar dalam dunia pendidikan.

Dalam kamus besar bahasa Indonesia, pengertian bahasa secara umum dapat didefenisikan sebagai lambang, serta pengertian bahasa menurut istilah adalah alat komunikasi yang berupa sistem lambang yang dihasilkan oleh alat ucap pada manusia. Menurut Pateda (1987:4) bahwa bahasa merupakan saluran untuk menyampaikan semua yang dirasakan, dipikirkan, dan diketahui seseorang kepada orang lain. Bahasa juga memungkinkan manusia dapat bekerja sama dengan orang lain dalam masyarakat. Hal tersebut berkaitan erat bahwa hakikat manusia sebagai makhluk sosial memerlukan bahasa untuk memenuhi hasratnya. Bahasa berperan meliputi segala aspek kehidupan manusia. Termasuk salah satu peran tersebut adalah untuk memperlancar proses sosial manusia.

Hal ini sejalan dengan pendapat Nababan (1984:38) bahwa bahasa adalah bagian dari kebudayaan dan bahasalah yang memungkinkan pengembangan kebudayaan sebagaimana kita kenal sekarang. Bahasa dapat pula berperan sebagai alat integrasi sosial sekaligus alat adaptasi sosial, hal ini mengingat bahwa Bangsa Indonesia memiliki bahasa yang majemuk. Menurut Wibowo, bahasa adalah sistem simbol bunyi yang bermakna dan berartikulasi (dihasilkan oleh alat ucap) yang bersifat arbitrer dan konvensional, yang dipakai sebagai alat berkomunikasi oleh sekelompok manusia untuk melahirkan perasaan dan pikiran. Pengertian bahasa juga diungkapkan oleh
Pengabean, bahwa bahasa adalah suatu sistem yang mengutarakan dan melaporkan apa yang terjadi pada sistem saraf. Selain pengertian bahasa yang diutarakan oleh Wibowo dan Pangabean, Soejono (2004:30) juga turut mengutarakan pengertian bahasa, menurutnya bahasa adalah suatu sarana perhubungan rohani yang amat penting dalam hidup bersama. Dari semua pendapat yang diutarakan oleh para ahli dapat disimpulkan bahwa, bahasa adalah sarana komunikasi antara orang satu dengan orang yang lain untuk melakukan pertukaran informasi.

\section{PEMBAHASAN}

Sejarah Bahasa Indonesia "Kami, putra dan putri Indonesia menjunjung bahasa persatuan, bahasa Indonesia", demikianlah bunyi alenia ketiga sumpah pemuda yang telah dirumuskan oleh para pemuda yang kemudian menjadi pendiri bangsa dan negara Indonesia. Bunyi alenia ketiga dalam ikrar sumpah pemuda pada tanggal 28 Oktober 1928 itu jelas bahwa yang menjadi bahasa persatuan bangsa Indonesia adalah bahasa Indonesia. Kita sebagai bagian bangsa Indonesia sudah selayaknya menjunjung tinggi bahasa Indonesia dalam kehidupan sehari-hari. Dewasa ini pemakaian bahasa Indonesia baik dalam kehidupan sehari-hari mulai bergeser digantikan dengan pemakaian bahasa anak remaja yang dikenal dengan bahasa gaul. Interferensi bahasa gaul kadang muncul dalam penggunaan bahasa Indonesia dalam situasi resmi yang mengakibatkan penggunaan bahasa tidak baik dan tidak benar.

\section{Pengertian Bahasa Gaul}

Bahasa gaul merupakan salah satu cabang dari bahasa Indonesia sebagai 
bahasa untuk pergaulan. Istilah ini mulai muncul pada akhir ahun 1980-an. Bahasa gaul pada umumnya digunakan sebagai sarana komunikasi di antara remaja sekelompoknya selama kurun tertentu. Hal ini dikarenakan, remaja memiliki bahasa tersendiri dalam mengungkapkan ekspresi diri. Sarana komunikasi diperlukan oleh kalangan remaja untuk menyampaikan halhal yang dianggap tertutup bagi kelompok usia lain atau agar pihak lain tidak dapat mengetahui apa yang sedang dibicarakannya.

Menurut Mulyana (2008), bahasa gaul adalah sejumlah kata atau istilah yang mempunyai arti yang khusus, unik, menyimpang atau bahkan bertentangan dengan arti yang lazim ketika digunakan oleh orang-orang dari subkultur tertentu. Selain pendapat tersebut Sarwono (2004) mengatakan bahwa bahasa gaul adalah bahasa khas remaja (kata-katanya dibahubah sedemikian rupa, sehingga hanya bisa dimengeri di antara mereka) bisa dipahami oleh hampir seluruh remaja di tanah air yang terjangkau oleh media massa, padahal istilah istilah itu berkembang, berubah dan bertambah hampir setiap hari. Kedua defenisi itu saling melengkapi. Pada defenisi yang pertama hanya menerangkan bahwa bahasa gaul adalah bahasa yang mempunyai istilah yang unik, sedangkan defenisi yang kedua diperjelas lagi bahwa yang menggunakan bahasa tersebut adalah para remaja dan bahasa tersebut akan terus berkembang.

\section{Ciri-ciri Bahasa Gaul}

Ragam bahasa gaul remaja memiliki ciri khusus, yaitu: singkat, lincah dan kreatif. Kata-kata yang digunakan cenderung pendek, sementara kata yang agak panjang akan diperpendek melalui proses morfologi atau menggantinya dengan kata yang lebih pendek.

1. Kosakata khas:

\begin{tabular}{|l|l|}
\hline $\begin{array}{l}\text { Kosa kata Bahasa } \\
\text { Indonesia }\end{array}$ & $\begin{array}{l}\text { Kosa kata } \\
\text { bahasa gaul }\end{array}$ \\
\hline Aku & Gua, gue, gwa \\
\hline Ayah/ Bapak & Bokap \\
\hline Cantik & Kece \\
\hline Ibu & Nyokab \\
\hline Kamu & Lu, lo, elu \\
\hline
\end{tabular}

2. Penghilangan huruf (fonem) awal

\begin{tabular}{|l|l|}
\hline Fonem awal & $\begin{array}{l}\text { Fonem sudah } \\
\text { dihilangkan }\end{array}$ \\
\hline Memang & Emang \\
\hline Sama & Ama \\
\hline Saja & Aja \\
\hline Sudah & Udah \\
\hline
\end{tabular}

3. Penghilangan huruf " $h$ ":

\begin{tabular}{|l|l|}
\hline Bohong & Boong \\
\hline Habis & Abis \\
\hline Hangat & Anget \\
\hline Hitung & Itung \\
\hline Hujan & Ujan \\
\hline
\end{tabular}

4. Penggantian huruf "a" dengan "e":

\begin{tabular}{|l|l|}
\hline Benar & Bener \\
\hline Cakap & Cakep \\
\hline Sebal & Sebel \\
\hline Senang & Seneng \\
\hline
\end{tabular}

5. Penggantian diftong "au", "ai" dengan "o" dan "e":

\begin{tabular}{|l|l|}
\hline Capai & Cape \\
\hline Kalau & Kalo \\
\hline Pakai & Pake \\
\hline Sampai & Sampe \\
\hline
\end{tabular}

6. Pemendekan kata atau kontraksi dari kata/frasa yang panjang:

\begin{tabular}{|l|l|}
\hline Bagaimana & Gimana \\
\hline Begini & Gini \\
\hline Begitu & Gitu \\
\hline Ini & Nih \\
\hline
\end{tabular}


Faktor-faktor Pendukung Maraknya Bahasa Gaul di Kalangan Remaja

Perkembangan bahasa gaul di kalangan remaja sangatlah cepat. Mengapa?? Karena didukung oleh beberapa faktor yang cukup berpengaruh terhadap kondisi lingkungan remaja, antara lain:

a. Adanya bahasa gaul ditandai dengan menjamurnya internet dan situs-situs jejaring sosial yang berdampak signifikan terhadap perkembangan bahasa gaul. Penikmat situs-situs jejaring sosial yang kebanyakan adalah remaja, menjadi agen dalam menyebarkan pertukaran bahasa gaul.Tulisan seorang remaja di situs jejaring sosial yang menggunakan bahasa ini, akan dilihat dan bisa jadi ditiru oleh ribuan remaja lain. Misalnya, facebook, twitter, friendster.

b. Karena pengaruh lingkungan. Umumnya para remaja menyerap dari percakapan orang-orang dewasa di sekitarnya, baik teman sebaya atau keluarga.

c. Peran media, antara lain: (1) media elektronik yang menggunakan istilah bahasa gaul dalam film-film khusunya film remaja dan iklan, misal dari adegan percakapan di televisi. Aritnya bahasa gaul tidak hanya terjadi karena kontak langsung antara masyarakat itu sendiri, tapi sebagian besar karena "disuapi” oleh media; (2) media cetak, misalnya bahasa yang ada dalam majalah, surat kabar atau koran. Selain itu, pembuatan karya sastra remaja misalnya cerpen atau novel yang umumnya menggunakan bahasa gaul.

d. Dampak dari pembangunan dan perkembangan zaman atau modernisasi, dimana segala hal yang ada di lingkungan kita harus selalu ter up-to date. Dampak dari modernisasi yang paling terlihat adalah gaya hidup, seperti cara berpakaian, cara belajar, aplikasi teknologi yang makin maju maupun cara bertutur kata (pemakaian bahasa). Yang pasti, bahasa gaul akan selalu muncul dan berkembang sesuai zaman masing-masing. Beberapa tahun lalu, istilah "memble aje" atau "Biarin, yang penting kece" sempat ngetren. Istilah-istilah tersebut lantas tenggelam dengan sendirinya, tergantikan oleh istilah lain. Di antaranya, "so what gitu loh", "jayus", dan "Kesian deh lo!".

\section{Pengaruh Bahasa Gaul terhadap Bahasa Indonesia}

Dewasa ini, masyarakat sudah banyak yang memakai bahasa gaul dan parahnya lagi generasi muda Indonesia juga tidak terlepas dari pemakaian bahasa gaul ini. Bahkan generasi muda inilah yang banyak memakai bahasa gaul dari pada pemakaian bahasa Indonesia. Untuk menghindari pemakaian bahasa gaul yang sangat luas di masyrakat, seharusnya kita menanamkan kecintaan dalam diri generasi bangsa terhadap bahasa Indonesia sebagai bahasa nasional. Seiring dengan munculnya bahasa gaul dalam masyarakat, banyak sekali dampak atau pengaruh yang ditimbulkan oleh bahasa gaul terhadap perkembangan bahasa Indonesia sebagai identitas bangsa diantaranya sebagai berikut:

a. Eksistensi Bahasa Indonesia Terancam Terpinggirkan Oleh Bahasa Gaul. Berbahasa sangat erat kaitannya dengan budaya sebuah generasi. Kalau generasi negeri ini kian tenggelam dalam pudarnya bahasa Indonesia yang 
lebih dalam, mungkin bahasa Indonesia akan semakin sempoyongan dalam memanggul bebannya sebagai bahasa nasional dan identitas bangsa. Dalam kondisi demikian, diperlukan pembinaan dan pemupukan sejak dini kepada generasi muda agar mereka tidak mengikuti pembusukan itu. Pengaruh arus globalisasi dalam identitas bangsa tercermin pada perilaku masyarakat yang mulai meninggalkan bahasa Indonesia dan terbiasa menggunakan bahasa gaul.

b. Menurunnya Derajat Bahasa Indonesia. Karena bahasa gaul yang begitu mudah untuk digunakan berkomunikasi dan hanya orang tertentu yang mengerti arti dari bahasa gaul, maka remaja lebih memilih untuk menggunakan bahasa gaul sebagai bahasa sehari-hari. Sehingga bahasa Indonesia semakin pudar bahkan dianggap kuno di mata remaja dan juga menyebabkan turunnya derajat bahasa indonesia.

c. Menyebabkan punahnya Bahasa Indonesia. Penggunaan bahasa gaul yang semakin marak di kalangan remaja merupakan sinyal ancaman yang sangat serius terhadap bahasa indonesia dan pertanda semakin buruknya kemampuan berbahasa generasi muda zaman sekarang. Sehingga tidak dapat dipungkiri suatu saat bahasa Indonesia bisa hilang karena tergeser oleh bahasa gaul di masa yang akan datang.

\section{Dampak dari Penggunaan Bahasa Gaul}

\section{Dampak Positif}

Dampak positif dengan digunakannya bahasa gaul adalah remaja menjadi lebih kreatif. Terlepas dari menganggu atau tidaknya bahasa gaul ini, tidak ada salahnya kita menikmati tiap perubahan atau inovasi bahasa yang muncul. Asalkan dipakai pada situasi yang tepat, media yang tepat dan komunikan yang tepat juga.

\section{Dampak Negatif}

Penggunaan bahasa gaul dapat mempersulit pengguna bahasa Indonesia dengan baik dan benar. Padahal di sekolah atau di tempat kerja, kita diharuskan untuk selalu menggunakan bahasa yang baik dan benar. Bahasa gaul dapat mengganggu siapapun yang membaca dan mendengar kata-kata yang termaksud di dalamnya. Karena, tidak semua orang mengerti akan maksud dari kata-kata gaul tersebut. Terlebih lagi dalam bentuk tulisan, sangat memusingkan dan memerlukan waktu yang lebih banyak untuk memahaminya. Bahasa gaul dapat mempersulit penggunanya dalam berkomunikasi dengan orang lain dalam acara yang formal. Misalnya ketika sedang presentasi di depan kelas.

\section{Pengaruh Bahasa terhadap Budaya}

Kebudayaan adalah hasil cipta, rasa, dan karsa manusia. Bahasa menentukan harkat, martabat, sikap dan perilaku seseorang (Sapir, 1927 dan Whorf, B.E.1956). Bahasa memengaruhi perilaku manusia. Ragam bahasa pada hakikatnya adalah variasi penggunaan bahasa oleh para penetur bahasa itu. Dengan konsep itu, keberadaan bahasa Indonesia resmi (baku) dalam penggunaan bahasa Indonesia oleh para penuturnya merupakan salah satu bentuk variasi bahasa dari variasi bahasa Indonesia lainnya. Hal penting yang perlu di pahami adalah bahwa bahasa Indonesia menjadi alasan digunakannya bahasa resmi tersebut. Ragam bahasa Indonesia 
dibedakan Alwi (1998: 3-6) berdasarkan penutur bahasa dan berdasarkan jenis pemakaian bahasa. Ragam bahasa Indonesia berdasarkan penutur diperinci menurut tinjauan. Sudaryanto (199: 50), yakni (1) bahasa Indonesia ragam jurnalistik, (2) bahasa Indonesia ragam literasi, (3) bahasa Indonesia ragam filosofik, (4) bahasa Indonesia ragam akademik, (5) bahasa Indonesia ragam bisnis.

Ragam-ragam bahasa Indonesia dapat dijelaskan berikut ini:

1. Berdasarkan daerah asal penutur, bahasa Indonesia yang digunakan oleh orang Indonesia memiliki variasi atau ragam. Ragam-ragam bahasa Indonesia dari sudut daerah penutur ini sering disebut dengan logat. Dengan demikian akan terdapat beberapa ragam bahasa Indonesia, yakni bahasa Indonesia logat Batak, logat Minangkabau, logat Jawa, logat Aceh, logat Sunda, logat Bali, logat Manado, logat Melayu dan sebagainya.

2. Berdasarkan pendidikan penutur, bahasa Indonesia dibedakan atas beberapa ragam atau variasi. Dari sudut itu, kelihatan bahwa bahasa Indonesia memiliki variasi penggunaannya. Bahasa Indonesia yang digunakan oleh orang yang berpendidikan berbeda dengan bahasa Indonesia yang digunakan oleh orang yang tidak berpendidikan. Oleh karena itu, dapat dibedakan adanya bahasa Indonesia ragam orang berpendidikan dan bahasa Indonesia ragam orang tidak berpendidikan.

3. Berdasarkan sikap penutur, ragam bahasa Indonesia menurut sikap penutur disebut dengan ragam atau gaya. Oleh karena itu, bahasa Indonesia yang digunakan para penutur berdasarkan sikapnya dapat dibedakan atas beberapa macam, yakni Bahasa Indonesia ragam resmi, ragam akrab, ragam santai, dan sebagainya.

4. Berdasarkan pokok persoalan, setiap pokok persoalan atau bidang yang dibicarakn telah memperlihatkan bahwa variasi bahasa Indonesia sesuai dengan bidang itu. Bahasa Indonesia yang digunakan dalam bidang militer telah memperlihatkan kekhasannya atau berbeda dengan bahasa Indonesia yang digunakan dalam bidang kedokteran. Penggunaan istilah operasi dalam bidang kedokteran akan berbeda dengan penggunaan istilah operasi dalam bidang militer. Jadi, rgam bahasa menurut pokok persoalan dibedakan atas ragam bahasa dibidang agama, politik, militer, teknik, kedokteran, seni, dan sebagainya.

5. Berdasarkan sarana, bahasa Indonesia lisan masing-masing memiliki variasi dengan bahasa Indonesia tulis. Bahasa Indonesia tulis telah tidak lagi persis sama dengan bahasa Indonesia lisan. Hal itu terjadi karena bahasa Indonesia tulis telah diatur dengan sistem atau aturannya sendiri. Akhirnya, Bahasa Indonesia lisan memiliki kekhasan dan bahasa Indonesia tulis juga memiliki kekhasan. Namun, kadang-kadang perlu dicermati bahwa tidak semua bahasa Indonesia yang dilisankan sebagai ragam lisan karena mungkin yang lisan itu pada hakikatnya adalah bahasa Indonesia ragam tulis.

6. Berdasarkan gangguan percampuran, bahasa Indonesia pemakainnya telah diperlihatkan adanya ragam yang mengalami percampuran dengan bahasa asing dan ragam yang tidak mengalami 
percampuran. Hal itu terlihat apabila bahasa Indonesia digunakan oleh para penuturnya terutama penutur ditingkat atas. Oleh karena itu, pada dasarnya bahasa Indonesia yang mengalami percampuran dan ragam bahasa Indonesia yang tidak mengalami percampuran.

\section{Sikap Penutur Bahasa terhadap Bahasa Indonesia Baku.}

Fungsi pemersatu dan penanda kepribadian membangkitkan sikap setia terhadap bahasa Indonesia. Kesetiaan berbahasa Indonesia dapat dikembangkan, jika orang diberi motivasi supaya mau mempelajari bahasa itu. Fungsi pembawa wibawa dikaitkan dengan sikap kebanggaan berbahasa Indonesia baku, orang merasa bangga jika mampu berbahasa Indonesia yang baik, karena itu ia dianggap termasuk kalangan yang terpelajar atau golongan yang terkemuka. Fungsi kerangka acuan bahasa Indonesia yang baku berhubungan dengan merekahnya kesadaran orang akan adanya suatu aturan baku yang patut diladeni, kepatuhan orang pada aturan baku itu akan menghindarkannya dari sanksi sosial sebagaimana orang berusaha berbahasa inggris dengan baik karena takut ditertawakan.

\section{KESIMPULAN}

Dari penulisan karya ilmiah diatas mengenai "Pudarnya penggunaan Bahasa Indonesia oleh Bahasa Gaul di kalangan remaja" dapat diambil kesimpulan bahwa banyaknya masyarakat Indonesia yang menggunakan bahasa gaul, singkatansingkatan dalam komunikasinya seharihari adalah penyimpangan dari penggunaan Bahasa Indonesia dengan baik dan benar. Hal ini dapat menghambat pertumbuhan dan perkembangan Bahasa Indonesia. Kurangnya kesadaran untuk mencintai dan menggunakan Bahasa Indonesia di Negeri sendiri akan berdampak lunturnya atau hilangnya Bahasa Indonesia dalam pemakaiannya dalam masyarakat terutama di kalangan remaja. Apalagi dengan maraknya dunia kalangan artis menggunakan bahasa gaul di media massa dan elektronik, membuat remaja semakin sering menirukannya di kehidupan seharihari hal ini sudah wajar karena remaja suka meniru hal-hal yang baru.

\section{DAFTAR PUSTAKA}

As'ad, Sungguh. 2016. Pedoman Umum Ejaan Bahasa Indonesia Dan Pembentukaan Istilah. Jakarta: Bumi Askara.

Baiqjulia. 2014. Karya Ilmiah Pudarnya Penggunaan Bahasa Indonesia. (Online, http://baiqjulia.biogspot.com/2014/01/karya-ilmiah-pudarnya-penggunaan-bahasaindonesia_26.html? $\mathrm{m}=1$, Diakses 23 Desember 2018).

Ermanto \& Emidar. 2018. Bahasa Indonesia,Pengembangan Kepribadian di Perguruan Tinggi. Depok. Kharisma Putra Utama Offset.

Mahsun, 2005. Metode Penelitian Bahasa. Jakarta: Kharisma Putra Utama Offset.

Mansyur, Umar. 2016. Bahasa Indonesia dalam Belitan Media Sosial: Dari Cabe-Cabean Hingga Tafsir Al-Maidah 51. In Prosiding Seminar Nasional \& Dialog Kebangsaan dalam Rangka Bulan Bahasa 2016 (pp. 145-155). Fakultas Ilmu Budaya Universitas 
Hasanuddin. https://doi.org/10.31227/osf.io/7vpjh.

Mansyur, Umar. 2018. Kiat dan Teknik Penulisan Skripsi bagi Mahasiswa. INA-Rxiv. https://doi.org/10.31227/osf.io/juds7.

Putry. 2014. Pudarnya Penggunaan Bahasa Indonesia. (Online, http://putrysosiologi.biogspot.com/2014/06/pudarnya-penggunaan-bahasa-indonesia_ 26.html?m=1, Diakses 23 Desember 2018).

Samsuri, 1985. Analisis Bahasa. Jakarta: Erlangga.

Pranowo, 2009. Kesantunan Berbahasa Tokoh Masyarakat, Ditinjau dari Aspek Pragmatik. Yogyakarta: Sidang Terbuka 